\title{
Palkoviljat nautojen ruokinnassa
}

Laura Puhakka, Seija Jaakkola, Aila Vanhatalo

Helsingin yliopisto, Maataloustieteiden laitos, PL 28, 00014 Helsingin yliopisto

etunimi.sukunimi@helsinki.fi

\section{Tiivistelmä}

Kotieläintilojen rehuntuotanto perustuu pitkälti typpilannoituksella tuotettuihin perusrehuihin ja valkuaisrehujen osalta tuontivalkuaiseen, joten karjatalous on suuressa määrin riippuvainen ulkomaisista tuotantopanoksista ja niiden hinnoista. Typpeä sitovien palkoviljojen nykyistä laajempi viljely ja käyttöönotto eläinten ruokinnassa voisi parantaa kotieläintuotannon energia- ja valkuaisomavaraisuutta. Palkoviljojen, kuten herneen, härkäpavun ja lupiinin käytöstä nautojen rehuna Suomessa on melko niukasti tutkimustietoa. Tässä kirjallisuuteen perustuvassa esityksessä tarkastellaan palkoviljojen ravitsemuksellisia ominaisuuksia ja soveltuvuutta erityisesti nautakarjan ruokintaan.

Herne ja härkäpapu ovat vanhastaan tunnettuja valkuaispitoisia palkoviljoja ja niitä voidaan viljellä myös kokoviljasäilörehuksi. Kotimaisten tutkimusten mukaan herneen siemen soveltuu hyvin lypsylehmien rehuksi, mutta valkuaisarvoltaan se ei ole aivan rypsin veroinen. Herneen siemenessä on valkuaista noin puolet rypsirehujen pitoisuuksista, eli reilut $200 \mathrm{~g} / \mathrm{kg}$ kuiva-ainetta. Herneen valkuainen hajoaa suurelta osin jo pötsissä, joten siinä ei ole samalla tavalla ohitusvalkuaista kuten rypsirehuissa. Herne sisältää kuitenkin runsaasti tärkkelystä, joten se voi lisätä pötsimikrobien energian saantia ja vaikuttaa edullisesti mikrobivalkuaisen tuotantoon pötsissä. Myös kokoviljasäilörehun täydentäjäksi herne sopii hyvin, koska kokoviljasäilörehun valkuaispitoisuus on tyypillisesti pieni. Härkäpavusta ja lupiineista lypsylehmien rehuna ei ole juuri kotimaisia tutkimustuloksia. Härkäpavun siemen sisältää tärkkelystä vähemmän, mutta valkuaista selvästi enemmän kuin herne, n. $300 \mathrm{~g} / \mathrm{kg}$ kuivaainetta. Lupiinien valkuaispitoisuus on jonkin verran suurempi kuin härkäpavun. Ne poikkeavat herneestä ja härkäpavusta siten, että niiden tärkkelyspitoisuus on pieni. Sen sijaan lupiinit sisältävät rasvaa, muun muassa öljyhappoa, ja helppoliukoisia hiilihydraatteja. Yhteistä kaikille palkoviljoille on, että rypsirehuihin verrattuna niiden valkuainen sisältää vain niukasti rikkipitoisia aminohappoja kuten metioniinia. Toisaalta palkoviljojen etuna rypsiin nähden on, että ne sisältävät selvästi vähemmän fosforia, joten tässä suhteessa ne eivät kuormita ympäristöä niin paljon kuin rypsi. Ulkomaisten tutkimusten mukaan härkäpavun ja lupiinin maidontuotantovaikutus on joissakin kokeissa ollut jopa soijan luokkaa. Hernettä ja härkäpapua voidaan korjata palkojen täyttymisvaiheessa ennen tuleentumista myös kokoviljasäilörehuksi. Hernevilja-säilörehua voidaan syöttää lypsylehmille joko ainoana karkearehuna tai seoksena nurmirehun kanssa. Härkäpavusta kokoviljasäilörehuna on melko niukasti kotimaisia tutkimustuloksia. Myös valkolupiini on kiinnostava rehukasvi. Suomen olosuhteissa se ei ehdi tuleentua, mutta hyvän sadontuottokykynsä vuoksi se on mielenkiintoinen kokoviljasäilörehun raaka-aine.

Asiasanat: herne, härkäpapu, kokoviljasäilörehu, lupiini, nauta, palkovilja,valkuainen 


\section{Johdanto}

Kotieläintilojen rehuntuotanto perustuu pitkälti typpilannoituksella tuotettuihin perusrehuihin ja valkuaisrehujen osalta tuontivalkuaiseen, joten karjatalous on suuressa määrin riippuvainen ulkomaisista tuotantopanoksista ja niiden hinnoista. Valkuainen on lypsylehmien rehuseosten kallein komponentti. Vaikka lehmät saavat merkittävän osan, noin $60 \%$, tarvitsemistaan aminohapoista mikrobivalkuaisesta, valkuaisrehun merkitys aminohappojen lähteenä on silti tärkeä ja se on lisääntymässä lehmien geneettisen tuotantopotentiaalin jatkuvan nousun myötä.

Kasviöljyn tuotannossa syntyvät rypsirehut ovat erinomaisia lypsylehmien valkuaisrehuja (Vanhatalo ym. 2004), mutta kotimainen tuotanto ei riitä tyydyttämään niiden kysyntää. Suomen valkuaisrehuomavaraisuus onkin alhainen, vain noin $15 \%$. Pitkälti sama tilanne on muualla Euroopassa, joten EU-tasolla oma tuotanto riittää kattamaan vain vajaan $30 \%$ valkuaisen tarpeesta. Tilannetta voidaan parantaa öljykasvien viljelyaloja lisäämällä, mutta se ei ole riittävä keino valkuaisomavaraisuuden saavuttamiseksi. Tämän vuoksi tarvitaan ennakkoluulotonta tutkimusta uusien valkuaiskasvien viljelymahdollisuuksien ja ruokintakäytön selvittämiseksi. Erityisesti typpeä sitovien palkoviljojen potentiaalin selvittämien maidontuotannon valkuais- ja energiaomavaraisuuden parantamisessa on ajankohtaista, sillä niiden viljelyyn liittyy useita positiivisia vaikutuksia sekä tilatasolla että kansantaloudellisesti. Valkuaisomavaraisuuden lisäämisellä varmistetaan tuotannon jatkuvuutta poikkeusolosuhteissa. Lisäksi se parantaa rehuihin liittyvien eläintautiriskien hallintaa ja edistää ruokaturvallisuutta.

Kotimaisia palkoviljoja ovat herne, härkäpapu ja sinilupiini. Tutkimusten mukaan ne ovat varteenotettavia viljelykasveja Suomessa (Stoddard ym. 2010). Lannoitussäästöjen lisäksi kasvintuotanto hyötyisi viljelykierron monipuolistumisesta. Palkoviljojen käytöstä nautojen rehuna Suomessa on melko niukasti tutkimustietoa. Juuri käynnistyneessä Helsingin yliopiston maataloustieteiden laitoksella toteutettavassa tutkimushankkeessa "Kotimaiset palkoviljat maidontuotannon omavaraisuuden tehostajana" tutkitaan härkäpavun ja sinilupiinin tuotantovaikutusta ja ravintoaineiden hyväksikäyttöä nurmisäilörehuun perustuvassa lypsylehmien ruokinnassa. Tässä kirjallisuuteen perustuvassa esityksessä tarkastellaan palkoviljojen ravitsemuksellisia ominaisuuksia ja soveltuvuutta erityisesti nautakarjan ruokintaan.

\section{Palkoviljojen ravitsemuksellinen arvo}

Yleisimmin kotieläinten ruokinnassa käytettyjä palkoviljoja ovat herne (Pisum sativum L.), härkäpapu (Vicia faba) ja lupiini (Lupinus spp.). Lukuisista eri lupiinilajeista rehuna viljellään sini- (Lupinus angustifolius) ja valkolupiinin (Lupinus albus) lisäksi myös esimerkiksi keltalupiinia (Lupinus luteus L.). Rehuvalkuaisen ominaisuuksista riippuen palkoviljojen ruokinnallinen arvo ja soveltuvuus voi olla hyvin erilainen eri eläinlajeilla. Valkuaisomavaraisuuden kannalta on oleellista, että käytettävissä olevat valkuaisrehut osataan suunnata oikeille eläinlajeille niin, että ne tulevat mahdollisimman tehokkaasti hyödynnettyä ja ruokinnan ravinnepäästöt minimoidaan.

Palkoviljoissa on suuri valkuaisen ja muuntokelpoisen energian pitoisuus, eläimet syövät niitä yleensä mielellään ja ne vaativat lyhyen totutuskauden (Dixon ja Hosking 1992). Lupiinilla on suuri rooli erityisesti Australiassa, jossa sitä on käytetty parantamaan uuhien lisääntymistehokkuutta (Stewart ja Oldham 1986). Myös lypsylehmien ruokinnassa lupiini on osoittautunut hyväksi rehuksi kun sillä on korvattu viljaa. Soijaa ja rypsiä korvattaessa maitotuotos on pysynyt muuttumattomana, mutta maidon valkuaispitoisuuden on todettu vähenevän (White ym. 2007). Pääasialliset rajoitukset palkoviljojen hyödyntämisessä märehtijöiden ruokinnassa ovat suuri pötsissä hajoavan valkuaisen osuus ja pieni rikkipitoisten aminohappojen pitoisuus. Suurin osa palkoviljoista sisältää sekundaarisia metaboliitteja, jotka ovat tärkeitä kasvin puolustautuessa hyönteisiä ja kasvinsyöjiä vastaan. Nämä haittaaineet vaikuttavat usein haitallisesti nisäkkäiden ravintoaineiden sulatukseen ja metaboliaan. Vain pieni osa palkoviljalajeista on yleistynyt käyttöön kehittyneissä maissa ja nämä on yleensä valittu niiden pienen tai kohtuullisen haitta-ainepitoisuuden perusteella. Palkoviljoissa usein esiintyvillä haittaaineilla, kuten lektiineillä ja proteinaasi-inhibiittoreilla on suuri merkitys erityisesti yksimahaisten ravitsemuksessa (Gatel 1994).

Herneen soveltuvuudesta lypsylehmien ruokintaan on käytettävissä kotimaisia tutkimustuloksia (Heikkilä ja Toivonen 1997, Khalili ym. 1999, Vanhatalo ym. 2004, Ahvenjärvi ym. 2005). Herneen siemen on lypsylehmälle käyttökelpoinen rehu. Se on useissa tutkimuksissa lisännyt maitotuotosta verrattuna kontrolliruokintaan, jossa ei ollut valkuaisrehua. Herneen valkuaisarvoa kuitenkin heikentää 
ja käyttöä rajoittaa valkuaisen suuri pötsihajoavuus, minkä vuoksi herneen tuotantovaikutus ja typen hyväksikäyttö on useissa ruokintatilanteissa huonompi kuin rypsin. Märehtijän rehun valkuaisarvoon vaikuttavat rehun valkuaispitoisuuden lisäksi valkuaisen hajoavuus pötsissä, pötsissä hajoamattoman valkuaisen sulavuus ohutsuolessa sekä hajoamattoman ohutsuolisulavan valkuaisen aminohappokoostumus. Valkuaisen suuren pötsihajoavuuden vuoksi herne soveltuu parhaiten ruokintatilanteisiin, joissa lypsylehmän karkearehun valkuaispitoisuus ei ole kovin suuri (esimerkiksi kokoviljasäilörehu tai vähän raakavalkuaista sisältävä nurmisäilörehu).

Härkäpavun ja lupiinin siementen käyttöä lypsylehmien ruokinnassa ei ole tutkittu Suomessa kuten on tehty yksimahaisilla eläimillä (mm. Palander ym. 2006, Partanen ym. 2006). Koska härkäpapua kuitenkin käytetään lehmien rehuna, on tutkimustiedon puute tullut esiin ruokintaneuvonnassa. Palkokasvien siementen koostumuksessa on eroja, jotka vaikuttavat rehuarvoon (Taulukko 1.). Siksi herneellä saatuja tuloksia ei voi soveltaa suoraan muihin palkokasveihin. Palkoviljojen kemiallinen koostumus voi vaihdella suuresti lajikkeiden välillä (Duc ym. 1999, Wang ja Daun 2004), kasvun ja kehityksen eri vaiheissa sekä sadonkorjuun ja varastoinnin olosuhteiden perusteella. Kotimaisessa rehutaulukossa (MTT 2010) raakavalkuaispitoisuus on härkäpavussa $300 \mathrm{~g} / \mathrm{kg}$ ka, rehuherneessä 230 $\mathrm{g} / \mathrm{kg} \mathrm{ka}$ ja lupiinissa $340 \mathrm{~g} / \mathrm{kg} \mathrm{ka}$. Soijarouheen raakavalkuaispitoisuus on puolestaan noin $500 \mathrm{~g} / \mathrm{kg} \mathrm{ka}$. Taulukossa 2 on esitetty palkoviljojen aminohappokoostumus. Palkoviljojen rikkiä sisältävien aminohappojen pitoisuus on yleensä pieni ja näin ollen typpi-rikki-suhde on suuri (Dixon ja Hosking 1992). Maidontuotantoa rajoittavista aminohapoista (Vanhatalo ym. 1999) härkäpapu ja lupiini sisältävät histidiiniä lähes yhtä paljon kuin rypsi, mutta metioniinia vähemmän.

Herneessä ja härkäpavussa energiavarastona on tärkkelys, mutta lupiinissa ja soijassa rasva. Esimerkiksi härkäpavun ja herneen siementen tärkkelyspitoisuus voi olla 400-500 g/kg ka, kun taas lupiinin tärkkelyspitoisuus $(100 \mathrm{~g} / \mathrm{kg} \mathrm{ka})$ on huomattavasti pienempi ja toisaalta NDF-pitoisuus (250 $\mathrm{g} / \mathrm{kg} \mathrm{ka}$ ) suurempi kuin herneen ja härkäpavun (MTT 2010). Lupiini sisältää myös helppoliukoisia hiilihydraatteja pektiiniä ja galaktaania (Eriksson 2010). Palkoviljojen tärkkelyksen pötsihajoavuus on laajamittaista ja nopeaa (Yu ym. 2002). Jalostettujen lupiinilajikkeiden siemenet sisältävät selvästi vähemmän rasvaa kuin soija, mutta lupiinin raakarasvan pitoisuus voi silti olla jopa lähes $100 \mathrm{~g} / \mathrm{kg}$ kuiva-ainetta (Froidmont ja Bartiaux-Thill 2004) ja rasvahappokoostumukseltaan se on verrattavissa rypsiöljyyn sisältäen runsaasti öljyhappoa, C18:1 (Woods ja Fearon 2009). Vaikka lupiinissa rasvapitoisuus voi olla enimmillään noin $100 \mathrm{~g} / \mathrm{kg}$ siemeniä, kuitenkin usein esimerkiksi Australiassa viljeltävien lajikkeiden rasvapitoisuus on pienempi (Dixon ja Hosking 1992). Kotimaisen rehutaulukon koostumustiedot härkäpavulle ja lupiinille perustuvat ulkomaisiin tutkimuksiin, joten on tarpeen tutkia kuinka tiedot vastaavat nykyisiä lajikkeita.

Härkäpavun valkuaisen pötsihajoavuus vastaa kirjallisuuden mukaan pitkälti hernettä. Sen sijaan lupiinin valkuaisen pötsihajoavuuden on esitetty olevan vähäisempää herneeseen verrattuna. Kotimaisen rehutaulukon (MTT 2010) hajoavan valkuaisen osuudet (hvo-arvot) lupiinille $(0,85)$ ja härkäpavulle $(0,80)$ ovat selvästi suurempia kuin soijalle $(0,75)$ ja rypsille $(0,70)$ ilmoitetut arvot. Eri lähteissä esitetyt palkoviljojen pötsihajoavuusarvot ovatkin hyvin ristiriitaisia johtuen osittain pötsihajoavuuden määritysmenetelmien ongelmista (Dixon ja Hosking 1992). Muun muassa Doreaun ym. 2010 mukaan lupiinin soijaa suurempi hvo-arvo johtuu nailonpussimenetelmän heikkouksista. Lampailla tehdyssä in vivo -kokeessa lupiinin valkuainen tuli soijaan verrattuna selvästi tehokkaammin hyväksikäytetyksi pötsissä. Erilaisilla käsittelyillä (esim. lämpö, formaldehydi) on myös pyritty vähentämään lupiinin valkuaisen hajoavuutta, mutta vaikutukset maitotuotokseen eivät ole olleet yhdenmukaisia (White ym. 2007). Yleisesti palkoviljojen esikäsittely vaikuttaa valkuaisen liukoisuuteen ja fermentaatioon (Dixon ja Hosking 1992). Esimerkiksi lupiinin pieni partikkelikoko lisäsi kuiva-aineen sulavuutta ja typen liukoisuutta (Freer ja Dove 1984), kun taas kokonaisten härkäpapujen ekstruusio vähensi pötsissä hajoavan valkuaisen määrää ja siten lisäsi valkuaisen sulavuutta ohutsuolessa (Cros ym. 1991). Kotimaisessa rehutaulukossa (MTT 2010) on vaatimus prosessoinnin vaikutuksen osoittamisesta tuotantokokeella haluttaessa muuttaa rehuvalkuaisen hvo-arvoa prosessoinnin vuoksi. Toistaiseksi ei ole olemassa luotettavaa menetelmää rehujen hvo-arvojen määrittämiseksi, vaikka tutkimustyötä luotettavien in vitro -menetelmien kehittämiseksi on meneillään (Ahvenjärvi ym. 2009). Vasta vähän tutkittujen palkoviljojen ruokinnallisen arvon selvittämiseksi on tärkeää saada tietoa niiden tuotantovaikutuksesta verrattuna rypsiin, jonka tuotosvasteet kotimaisessa nurmisäilörehun käyttöön perustuvassa ruokinnassa tunnetaan erittäin hyvin (Vanhatalo ym. 2004). 
Taulukko 1. Palkoviljojen kemiallinen koostumus, g/kg kuiva-ainetta ellei toisin mainittu (MTT 2010)

\begin{tabular}{lcrr}
\hline & $\begin{array}{l}\text { Herne } \\
\text { (Pisum } \\
\text { sativum) }\end{array}$ & $\begin{array}{c}\text { Härkäpapu } \\
\text { (Viciafaba) }\end{array}$ & $\begin{array}{c}\text { Lupiini } \\
\text { (Lupinus } \\
\text { spp.) }\end{array}$ \\
\hline Kuiva-aine, g/kg & 860 & 860 & 860 \\
Raakavalkuainen & 230 & 300 & 340 \\
Raakarasva & 11 & 15 & 51 \\
Raakakuitu & 57 & 80 & 178 \\
Typettömät uuteaineet & 676 & 565 & 401 \\
NDF & 130 & 160 & 250 \\
Tuhka & 26 & 40 & 30 \\
Tärkkelys & 480 & 380 & 100 \\
Sokeri & 55 & 40 & 55 \\
\hline
\end{tabular}

Taulukko 2. Palkoviljojen ja valkuaisrehujen (soija, rypsi) aminohappokoostumus (g/16 g N). Herneen, härkäpavun ja sinilupiinin arvot Schumacherin (2011), valkolupiinin arvot Sujakin ym. (2006) ja rypsirouheen sekä soijapavun arvot MTT (2010) mukaan.

\begin{tabular}{|c|c|c|c|c|c|c|}
\hline $\begin{array}{l}\text { Aminohapot (g/16 } \\
\mathrm{g} \mathrm{N})\end{array}$ & $\begin{array}{l}\text { Herne } \\
\text { (Pisum } \\
\text { sativum) }\end{array}$ & $\begin{array}{l}\text { Härkäpapu } \\
\text { (Vicia faba) }\end{array}$ & $\begin{array}{l}\text { Sinilupiini } \\
\text { (Lupinus } \\
\text { angustifolius) }\end{array}$ & $\begin{array}{l}\text { Valkolupiini } \\
\text { (Lupinus } \\
\text { albus) } \\
\end{array}$ & Rypsirouhe & $\begin{array}{l}\text { Soijapapu } \\
\text { (Glysine } \\
\text { max) }\end{array}$ \\
\hline \multicolumn{7}{|l|}{ Välttämättömät } \\
\hline Arginiini & 8,5 & 8,8 & 10,1 & 11,4 & 5,8 & 7,2 \\
\hline Fenyylialaniini & 4,9 & 4,2 & 4,0 & 3,9 & 4,1 & 5,0 \\
\hline Histidiini & 2,4 & 2,4 & 2,7 & 3,3 & 2,8 & 2,6 \\
\hline Isoleusiini & 4,4 & 4,2 & 4,3 & 4,3 & 3,9 & 4,8 \\
\hline Leusiini & 7,2 & 7,1 & 7,0 & 7,8 & 7,0 & 7,6 \\
\hline Lysiini & 7,3 & 6,3 & 4,8 & 4,9 & 5,8 & 6,0 \\
\hline Metioniini & 1,0 & 0,7 & 0,7 & 0,6 & 1,8 & 1,5 \\
\hline Treoniini & 3,8 & 3,4 & 3,5 & 3,5 & 4,4 & 4,0 \\
\hline Valiini & 4,9 & 4,6 & 4,2 & 4,1 & 4,9 & 5,0 \\
\hline \multicolumn{7}{|l|}{ Ei välttämättömät } \\
\hline Alaniini & 4,4 & 3,9 & 3,4 & 3,2 & 4,5 & 4,2 \\
\hline Asparagiinihappo & 11,1 & 10,1 & 9,5 & 10,5 & 7,1 & 18,5 \\
\hline Glutamiinihappo & 16,6 & 16,0 & 21,1 & 23,5 & 17,3 & 18,5 \\
\hline Glysiini & 4,4 & 4,2 & 4,2 & 4,3 & 5,0 & 4,2 \\
\hline Kystiini & 1,4 & 1,1 & 1,5 & 1,9 & 1,5 & 1,5 \\
\hline Proliini & 3,5 & 3,5 & 3,7 & 3,5 & 6,2 & 5,2 \\
\hline Seriini & 4,3 & 4,3 & 4,5 & 4,5 & 4,3 & 5,0 \\
\hline Tyrosiini & 3,6 & 3,5 & 3,8 & 1,7 & 2,7 & 3,0 \\
\hline
\end{tabular}

\section{Palkoviljojen haitta-aineet}

Palkoviljat sisältävät haitta-aineita, jotka saattavat rajoittaa niiden käyttöä varsinkin yksimahaisten eläinten ruokinnassa. Kotimaisista palkoviljoista herne ja härkäpapu sisältävät trypsiini-inhibiittoreita ja tanniineja ja härkäpapu lisäksi visiiniä ja konvisiiniä. Jotkut lupiinilajikkeet saattavat sisältää alkaloideja. Pötsimikrobien hajotustoiminnan ansiosta märehtijät eivät ole haitta-aineille yhtä herkkiä kuin yksimahaiset eläimet. Ulkomaisten lähteiden mukaan palkoviljoja voidaan sisällyttää lypsylehmien rehuannoksiin jopa raakana useita kiloja päivässä ilman haittavaikutuksia (mm. Melicharová ym. 2008, Melicharová ym. 2009), Vähäisen viljelyn vuoksi palkoviljojen haitta-ainepitoisuuksia Suomen olosuhteissa ei ole juuri tutkittu.

\section{Palkoviljojen tuotantovaikutus lypsylehmien ruokinnassa}

Muutamissa tutkimuksissa on testattu härkäpapua valkuaisen lähteenä soijan sijasta. Italialaisessa tutkimuksessa (Volpelli ym. 2010) pyrittiin löytämään gmo-vapaa valkuaisrehuvaihtoehto parmesaanijuustomaidon tuotantoa varten. Kahden kokeen perusteella todettiin, että maitotuotos ei heikentynyt vaikka osa väkirehun sisältämästä soijavalkuaisesta korvattiin härkäpavulla. Härkäpapua käytettäessä 
maidon ja plasman ureapitoisuudet olivat pienempiä kuin soijaa käytettäessä viitaten härkäpavun valkuaisen parempaan hyväksikäyttöön. Lupiinin vaikutuksista maidontuotannossa on saatu vaihtelevia tutkimustuloksia johtuen mahdollisesti eroista lupiinilajikkeissa ja erityyppisistä ruokintatilanteista (White ym. 2007). Parhaimmillaan lupiinin on todettu voivan korvata soija korkeatuottoisen lypsylehmän ruokinnassa (esim. May ym. 1993, Froidmont ja Bartiaux-Thill 2004). Lupiinin rasva voi vaikuttaa myös maidon rasvakoostumukseen. White ym. (2007) totesivat yhteenvedossaan, että verrattuna soijaruokintaan lupiini lisäsi öljyhapon (C18:1) pitoisuutta ja samalla tyydyttyneiden (C12:0C16:0) rasvahappojen pitoisuus väheni. Nämä vaikutukset ovat positiivisia ihmisterveyden kannalta. Lisäksi kivennäisruokintaa silmälläpitäen fosforipitoisuus on härkäpavussa $(6,5 \mathrm{~g} / \mathrm{kg} \mathrm{ka}) \mathrm{ja}$ lupiinissa $(6,5 \mathrm{~g} / \mathrm{kg} \mathrm{ka})$ selvästi pienempi kuin rypsirehuissa (12-13 g/kg ka), mikä on positiivinen tekijä pyrittäessä vähentämään valkuaisruokinnan negatiivisia ympäristövaikutuksia.

Lupiinin rehukäyttö lypsylehmien ruokinnassa on tällä hetkellä runsasta erityisesti Australiassa. Kiinnostus sitä kohtaan on lisääntynyt myös muualla ja lupiinin on esitetty olevan ainoa varteenotettava vaihtoehto soijalle esimerkiksi Britanniassa (Wilkins ja Jones 2000, Fraser ym. 2005). Koska viljelytutkimukset ovat osoittaneen tiettyjen lupiinilajikkeiden soveltuvan myös Suomeen, tulisi lupiinin ruokinnallista arvoa tutkia myös märehtijöillä. Myöskään härkäpavun maidontuotantovaikutuksesta ei ole saatavilla yhtään kotimaista tutkimustietoa. Edellä mainittujen kirjallisuustietojen perusteella lupiini saattaa olla myös meillä paras vaihtoehto palkoviljoista täydentämään lypsylehmän valkuaisruokintaa. Sekä härkäpavun että lupiinin tutkimus on tarpeen, jotta rehujen tuotantovaikutus ja ravintoaineiden hyväksikäyttö voidaan selvittää meille tyypilliseen nurmisäilörehuun perustuvassa ruokinnassa.

\section{Palkoviljat kokoviljasäilörehuina}

Palkokasveja voidaan hyödyntää myös korjaamalla koko kasvusto kokoviljasäilörehuna puhtaana tai seoksena viljojen kanssa. Palkokasveista saadaan runsas sato ja seoksissa ne vähentävät typpilannoituksen tarvetta, parantavat viljapohjaisten säilörehujen sulavuutta ja lisäävät raakavalkuaispitoisuutta. Suomessa on säilörehun raaka-aineena tutkittu hernettä, virnaa ja härkäpapua (mm. Pursiainen ym. 2004, Pursiainen ja Tuori 2008, Nykänen ym. 2009). Vihantarehuherneen käyttö onkin tähän tarkoitukseen lisääntynyt kotimaisilla tiloilla selvästi. Palkokasvien säilöntä on haasteellista niiden pienen kuiva-ainepitoisuuden, suuren puskurikapasiteetin ja suhteellisen pienen sokeripitoisuuden vuoksi (Borreani ym. 2009). Tämä on todettu erityisesti säilöttäessä puhtaita kasvustoja (Syrjälä-Qvist ym. 1982, Pursiainen ja Tuori 2008). Sen sijaan herneen, härkäpavun ja virnan säilöntä seoksena viljan kanssa sekä säilöntäaineen käyttö ja esikuivatus parantavat säilörehun säilönnällistä laatua (Pursiainen ja Tuori 2008). Saman totesivat Borreani ym. (2009) tutkiessaan rehuherneen, härkäpavun ja valkolupiinin säilöntää.

Valkolupiinin soveltuvuutta kokoviljasäilörehuksi ei ole tutkittu meidän olosuhteissamme. Valkolupiini on kuitenkin erittäin potentiaalinen kasvi käytettäessä sitä seoksena viljan kanssa esimerkiksi luomuviljelyssä (Azo ym. 2006). Uuden kasvilajin laajamittainen käyttö edellyttää tietoa kasvuston koostumuksesta, sulavuudesta ja säilöttävyydestä kasvukauden eri vaiheissa. Helsingin yliopistossa juuri alkaneessa hankkeessa selvitetään alustavasti mahdollisuuksia käyttää runsassatoista valkolupiinia kokoviljasäilörehun raaka-aineena.

\section{Kirjallisuus}

Ahvenjärvi, S., Stefanski, T. \& Huhtanen P. 2009. In vitro method for determining the ruminal degradation rate of rapeseed meal protein using ${ }^{15} \mathrm{~N}$ isotope labelled ammonia nitrogen. Animal Feed Science and Technology 153:88-100.

Ahvenjärvi, S., Vanhatalo, A. \& Jaakkola, S. 2005. Herne lisää lehmien maitotuotosta. Koetoiminta ja käytäntö 62, 2 (13.6.2005): s. 6.

Azo, W., M., Lane, G., P., F., Cannon, N., C. \& Davies, W., P. 2006. Dry matter yields and quality of organic lupin and lupin/cereal mixtures for wholecrop forage. Aspects of Applied Biology 79:93-96.

Borreani, G., Revello Chion, A., Colombini, S., Odoardi, M., Paoletti, R. \& Tabacco, E. 2009. Fermentative profiles of field pea (Pisum sativum), faba bean (Vicia faba) and white lupin (Lupinus albus) silages as affected by wilting and inoculation. Animal Feed Science and Technology 151:316-323.

Cros, P., Vernay, M. \& Moncoulon, R. 1991. In situ evaluation of the ruminal and intestinal degradability of extruded whole horsebeans. Reproduction Nutrition Development 31:249-255.

Dixon, R. M. \& Hosking, B. J. 1992. Nutritional value of grain legumes for ruminants. Nutrition Research Reviews 5:19-43. 
Doreau, M., Laverroux S., Chaucheuras-Durand, F., Poncet, C. 2010. Effect of N source (soyabean vs. whole lupin) and of yeast addition on digestion and ruminal metabolism in sheep. Energy and protein metabolism and nutrition. Ed. by G. M. Crovetto, EAAP publication No.127 pp. 569-570. Vageningen Academic Publishers.

Duc, G., Marget, P., Esnault, R., Le Guen, J. \& Bastianelli, D. 1999. Genetic variability for feeding value of faba bean seeds (Vicia faba): Comparative chemical composition of isogenics involving zero-tannin and zerovicine genes. Journal of Agricultural Science 133:185-196.

Eriksson, T. 2010. Nitrogen metabolism in dairy cows fed restricted amounts of grass-clover silage supplemented with seeds from narrow-leafed lupin or pea. Livestock Science 131:39-44.

Fraser, M. D., Fychan, R. \& Jones, R. 2005. Comparative yield and chemical composition of two varieties of narrow-leafed lupin (Lupinus angustifolius) when harvested as whole-crop, moist grain and dry grain. Animal Feed Science and Technology 120: 43-50.

Freer, M. \& Dove,H. 1984. Rumen degradation of protein in sunflower meal, rapeseed meal and lupin seed placed in nylon bags. Animal Feed Science and Technology 11:87-101.

Froidmont, E. \& Bartiaux-Thill, N. 2004. Suitability of lupin and pea seeds as a substitute for soybean meal in high-producing dairy cow feed. Animal Research 53: 475-487.

Gatel, F. 1994. Protein quality of legume seeds for non-ruminant animals: a literature review. Animal Feed Science and Technology 45:317-348.

Heikkilä, T. \& Toivonen, V. 1997. Herne ja rypsirouhe lehmien valkuaisrehuna säilörehuruokinnalla. Kotieläintieteenpäivät 1997. Maaseutukeskusten Liiton julkaisuja 914. p.187-190.

Khalili, H., Kuusela, E., Saarisalo, E. \& Suvitie, M. 1999. Use of rapeseed and pea grain protein supple-ments for organic milk production. Agricultural and Food Science in Finland 8: 239-252

May, M. G., Otterby, D. E., Linn J. G. \& Hansen, W. P. 1993. Lupins (Lupinus albus) as a protein supplement for lactating holstein dairy cows. Journal of Dairy Science 76:2682-2691.

Melicharová, V., Pechová, A., Dvořák, R., Pavlata, L. \& Lubojacká, V. 2008. Evaluation of performance and metabolism of dairy cows fed pea seeds (Pisum sativum) with different anti-nutritional content. Archiv Tierzucht, Dummerstorf 51:129-142.

Melicharová, V., Pechová, A., Dvořák, R. \& Pavlata, L. 2009. Performance and metabolism of dairy cows fed bean seeds (Vicia faba) with different levels of anti-nutritional substances. Acta Veterinaria Brno 78:57-66.

MTT 2010. Rehutaulukot ja ruokintasuositukset. URL = http://www.agronet.fi/rehutaulukot/ Viitattu 15.11.2011.

Nykänen, A., Jauhiainen, L. \& Rinne, M. 2009. Biomass production and feeding value of whole-crop cereal legume silages. Agronomy Research 7: 684-690.

Palander, S., Laurinen, P., Perttilä, S., Valaja, J. \& Partanen, K. 2006. Protein and amino acid digestibility and metabolizable energy value of pea (Pisum sativum), faba bean (Vicia faba) and lupin (Lupinus angustifolius) seeds for turkeys of different age. Animal Feed Science and Technology 127: 89-100

Partanen, K., Siljander-Rasi, H. \& Alaviuhkola, T. 2006. Feeding weaned piglets and growing-finishing pigs with diets based on mainly home-grown organic feedstuffs. Agricultural and Food Science 15: 89-105.

Pursiainen, P., Tuori, M., Karp, V. \& Leinonen, A-R. 2004. Herne-ohrakasvustosta säilörehua lypsylehmille. Maataloustieteen Päivät 2004, Suomen maataloustieteellisen seuran tiedote 19: 4 p.

Pursiainen, P. \& Tuori, M. 2008. Effect of ensiling field bean, field pea and common vetch in different proportions with whole-crop wheat using formic acid or an inoculant on fermentation characteristics. Grass and Forage Science 63: 60-78.

Schumacher, H., Paulsen, H. M., Gau, A. E., Link, W., Jürgens, H. U., Sass, O. \& Dieterich, R. 2011. Seed protein amino acid composition of important local grain legumes Lupinus angustifolius L., Lupinus luteus L., Pisum sativum L. and Vicia faba L. Plant Breeding 130: 156-164.

Stewart, R. \& Oldham, C.M. 1986. Feeding lupins for 4 days during the luteal phase can increase ovulation rate. Animal Production in Australia 16: 367-370.

Stoddard, F. L., Lizarazo, C., Mäkelä, P. \& Nykänen, A. 2010. New annual legume crops for Finnish conditions. Teoksessa: Anneli Hopponen (toim.) Maataloustieteen Päivät 2010 [Verkkojulkaisu]. Suomen maataloustieteellisen seuran julkaisuja no. 26. Viitattu [21.11.2011]. Julkaistu 11.1.2010.

Sujak, A. 2006. Compositional and nutritional evaluation of several lupin seeds. Food Chemistry 98:711-719.

Syrjälä-Qvist, L., Setälä, J., Kortesmaa, H. \& Pulli, S. 1982. Vihanta härkäpapu säilörehun raaka-aineena. Koetoiminta ja käytäntö 39, 11.5.1982: s. 29.

Vanhatalo, A., Ahvenjärvi, S. \& Jaakkola, S. 2004. Metabolic and production responses in dairy cows fed peas or rapeseed meal on grass silage based diet. In: The X International symposium on ruminant physiology: August 30th to September 4th 2004, Copenhagen, Denmark : short papers. Journal of Animal and Feed Sciences 13: (Suppl. 1) 231-234. 
Vanhatalo, A., Huhtanen, P., Toivonen, V. \&Varvikko, T. 1999. Response of dairy cows fed grass silage diets to abomasal infusions of histidine alone or in combinations with methonine and lysine. Journal of Dairy Science 82: 2674-2685.

Volpelli, L., Comellini, M., Masoero, F., Moschini, M., Lo Fiego, D. \& Scipioni, R. 2010. Faba beans (Vicia faba) in dairy cow diet: effect on milk production and quality. Italian Journal of Animal Science 9:e27.

Wang, N. \& Daun, J. K. 2004. Effect of variety and crude protein content on nutrients and certain antinutrients in field peas (Pisum sativum). Journal of the Science of Food and Agriculture 84:1021-1029.

White, C. L., Staines, V. E. \& Staines, M. v. 2007. A review of the nutritional value of lupins for dairy cows. Australian Journal of Agricultural Research 58: 185-202.

Wilkins, R.J. \& Jones, R. 2000. Alternative home-grown protein sources for ruminants in the United Kingdom. Animal Feed Science and Technology 85: 23-32.

Woods, V., B. \& Fearon, A., M. 2009. Dietary sources of unsaturated fatty acids for animals and their transfer into meat, milk and eggs: A review. Livestock Science 126:1-20.

Yu, P., Goelema, J. O., Leury, B. J., Tamminga, S. \& Egan, A. R. 2002. An analysis of the nutritive value of heat processed legume seeds for animal production using the DVE/OEB model: a review. Animal Feed Science and Technology 99:141-176. 